\title{
Improved synthesis and biological evaluation of an acyclic thiosangivamycin active against human cytomegalovirus*
}

\author{
Thomas E. Renau ${ }^{a}$, M. Reza Nassiri ${ }^{b}$, Eric E. Swayze ${ }^{c}$, Earl R. Kern ${ }^{\text {, }}$, \\ Leroy B. Townsend ${ }^{\mathrm{a}, \mathrm{c}}$ and John C. Drach ${ }^{\mathrm{a}, \mathrm{b}}$ \\ ${ }^{a}$ Interdepartmental Program in Medicinal Chemistry, College of Pharmacy, \\ ${ }^{\mathrm{b}}$ Department of Biologic and Materials Sciences, School of Dentistry, ' Department of Chemistry, \\ College of Literature, Science and Arts, University of Michigan, Ann Arbor, MI 48109 and \\ ${ }^{\mathrm{d}}$ Department of Pediatrics, University of Alabama at Birmingham, Birmingham, AL 35294, USA
}

(Received 28 October 1991; accepted 19 February 1992)

\begin{abstract}
Summary
We previously described the synthesis and in vitro antiviral activity of an acyclic thiosangivamycin analog (Gupta et al., 1989a). In order to extend these initial studies, a new, multi-gram synthesis of 4-amino-7-[(2-hydroxyethoxy)methyl]pyrrolo[2,3- $d$ ]pyrimidine-5-thiocarboxamide (compound 229) was achieved in 5 steps from the known 5-amino-2-bromo-3,4-dicyanopyrrole in good overall yield. In plaque reduction assays with HCMV, compound 229 had an $\mathrm{IC}_{50}$ of $7 \mu \mathrm{M}$; in yield reduction assays the $\mathrm{IC}_{90}$ was $25 \mu \mathrm{M}$. The compound was less active against MCMV, HSV-1, HSV-2, and least active against VZV. Concentrations of compound 229 up to $32 \mu \mathrm{M}$ did not affect the growth of KB cells for incubation periods up to $72 \mathrm{~h}$. At $100 \mu \mathrm{M}$, a prolongation in population doubling time from $21 \mathrm{~h}$ (untreated) to $35 \mathrm{~h}$ was noted. This inhibition, however, was reversible upon removal of the compound suggesting the inhibition was cytostatic rather than cytotoxic. Flow cytometric studies with compound 229 in HFF cells revealed an accumulation of cells in S
\end{abstract}

\footnotetext{
*Portions of this study were presented at the Fourth Annual International Conference on Antiviral Research, April 1991, New Orleans, LA.

Abbreviations: HCMV, human cytomegalovirus; HFF, human foreskin fibroblasts; HSV-1 and -2 , herpes simplex virus types 1 and $2 ; I_{50}$ or $\mathrm{IC}_{90}, 50$ or $90 \%$ inhibitory concentration; IR, infrared; MCMV, murine cytomegalovirus; MEM, minimum essential medium; PFU, plaque forming unit; NMR, nuclear magnetic resonance; TLC, thin-layer chromatography; VZV, varicella zoster virus.

Correspondence to: J.C. Drach, School of Dentistry, University of Michigan, Ann Arbor, MI 48109 1078 , USA.
} 
phase and a concurrent loss of cells in $G_{2} / M$ phase, suggesting an early $S$ phase blockage. We conclude there is adequate separation between antiviral activity and cytotoxicity to merit further work with this class of pyrrolopyrimidines.

HCMV; Acyclic nucleosides; Ganciclovir; Cellular-DNA content

\section{Introduction}

Human cytomegalovirus is the cause of debilitating and often life or sight threatening opportunistic infections in patients infected with human immunodeficiency virus and in other immunocompromised patients (Mills and Masur, 1990; Bowden, 1991). It also is a leading cause of birth defects as a result of congenital infection (Demmler, 1991). Currently, the drugs used to treat HCMV infections are ganciclovir (DHPG) and the newly approved foscarnet (PF). Both drugs, however, suffer from poor oral bioavailability and produce a number of adverse effects in both animals and humans (Shepp et al., 1985; Collaborative Study Group, 1986). In contrast, acyclovir is relatively non-toxic because it is phosphorylated to its corresponding monophosphate by a herpes virus encoded thymidine kinase (Elion et al., 1977; Fyfe et al., 1978). Unfortunately, acyclovir is not as effective as ganciclovir in inhibiting HCMV replication (Crumpacker et al., 1979; Tyms et al., 1981).

As part of our ongoing research with pyrrolo[2,3-d]pyrimidine nucleosides (Tolman et al., 1969), we have designed, synthesized, and evaluated a number of new analogs as potential antiviral agents (Townsend et al., 1991). Although the parent nucleoside antibiotics tubercidin, toyocamycin, and sangivamycin are active against $\mathrm{HCMV}$, they are equally cytotoxic in uninfected cells (Turk et al., 1987). In an attempt to limit cytotoxicity, we initiated studies involving specific chemical modifications of the nucleoside antibiotics per se. For example, we have synthesized a number of acyclic pyrrolo[2,3- $d$ ]pyrimidine derivatives containing either the acyclovir or ganciclovir side chain as potential HCMV agents (Saxena et al., 1988; Pudlo et al., 1988; Gupta et al., 1989a; Gupta et al., 1989b; Pudlo et al., 1990). These studies identified a series of acyclic bromotubercidins with potent activity against HCMV both in vitro and in vivo (Pudlo et al., 1988, 1990; Nassiri et al., 1990, 1991b). The initial antiviral evaluation of other compounds also identified a thiosangivamycin analog (4amino-7-[(2-hydroxyethoxymethyl)]pyrrolo[2,3- $d]$ pyrimidine-5-thiocarboxamide, compound $\left.229^{*}\right)$ as active against $\mathrm{HCMV}\left(\mathrm{IC}_{50}=11 \mu \mathrm{M}\right)$ without the severe cytotoxicity observed with toyocamycin and sangivamycin (Gupta et al., 1989a). To further evaluate the antiviral activity and cytotoxicity of compound 229 , sufficient quantities were required. However, the original synthetic scheme described by Gupta (1989a) was not suitable for supplying the multi-gram

*Referred to as compound 11 by Gupta et al., 1989a. 
quantities necessary for our more extensive studies. This prompted us to develop an alternate, multi-gram synthesis of compound 229 which facilitated a confirmation and extension of antiviral and cytotoxicity studies.

\section{Materials and Methods}

\section{Synthesis}

General methods. Melting points were taken on a Thomas-Hoover capillary melting point apparatus and are uncorrected. TLC was run on silica $60 \mathrm{~F}-254$ plates (Analtech, Inc.). Detection of components on TLC was made by UV light absorption at $254 \mathrm{~nm}$. Ultraviolet spectra were recorded on a HewlettPackard 8450 A spectrophotometer. IR spectra were taken on a Nicolet 5DXB infrared spectrometer. NMR spectra were determined at 270 or $360 \mathrm{MHz}$ with a BRUKER WP 270/360 SY. The chemical shift values are expressed in $\delta$ values (parts per million) relative to the standard chemical shift of the solvent DMSO- $d_{6}$ unless otherwise specified. Elemental analyses were performed by M-H-W Laboratories, Phoenix, AZ and are within $\pm 0.4 \%$ of the theoretical values. E. Merck silica gel (230-400 mesh) was used for flash column chromatography, which was carried out as described by Still and Kahn (1978). Evaporations were carried out under reduced pressure (water aspirator) with the bath temperature at $40^{\circ} \mathrm{C}$. Acetonitrile was distilled from $\mathrm{CaH}_{2}$.

1-[2-(acetoxyethoxy) methyl]-2-bromo-5-(ethoxymethylene) imino-pyrrole-3,4dicarbonitrile (3). A mixture of 2-amino-5-bromo-3,4-dicyanopyrrole (Swayze et al., 1991) (1, $2.11 \mathrm{~g}, 10.0 \mathrm{mmol})$ and distilled triethylorthoformate $(2.96 \mathrm{~g}, 20 \mathrm{mmol})$ in dry acetonitrile $(75 \mathrm{ml})$ under argon was heated at reflux for $2 \mathrm{~h}$, cooled to room temperature and the solvent evaporated in vacuo. The resulting residue was co-evaporated with toluene $(2 \times 100 \mathrm{ml})$ and rotary evaporated until a dry powder was obtained. The ${ }^{1} \mathrm{H}$ NMR spectrum of this compound agrees with structure $2: \delta 13.5(1 \mathrm{H}, \mathrm{s}, \mathrm{NH}), 8.40(1 \mathrm{H}, \mathrm{s}, \mathrm{CHN}), 4.28$ $\left(2 \mathrm{H}, \mathrm{q}, \mathrm{CH}_{3} \mathrm{CH}_{2} \mathrm{O}, \mathrm{J}=7.1 \mathrm{~Hz}\right), 1.30\left(3 \mathrm{H}, \mathrm{t}, \mathrm{CH}_{3} \mathrm{CH}_{2}, \mathrm{~J}=7.1 \mathrm{~Hz}\right)$. Crude 2 was dissolved in dry acetonitrile $(100 \mathrm{ml})$ then treated with sodium hydride $(60 \% \mathrm{w} /$ $\mathrm{w} \%, 0.60 \mathrm{~g}, 15 \mathrm{mmol})$ at room temperature. The mixture was stirred for $0.5 \mathrm{~h}$, then (2-acetoxyethoxy)methyl bromide (Robins and Hatfield, 1982) (3.94 g, 20 $\mathrm{mmol}$ ) was added dropwise. The reaction mixture was stirred at room temperature for $0.5 \mathrm{~h}$, then filtered. The filtrate was evaporated and the resulting oil subjected to flash column chromatography $\left(\mathrm{CHCl}_{3}\right)$ to yield a pale yellow oil. The compound was recrystallized from methanol to yield $2.12 \mathrm{~g}$ (55\%) of 3: $\mathrm{mp} 102-103^{\circ}$; TLC, $\mathrm{MeOH} / \mathrm{CHCl}_{3}(5: 95, \mathrm{v}: \mathrm{v}) \mathrm{Rf}=0.72$; FTIR (KBr) $v_{\max } 2227,1741,1725,1613,1243,1137,1111,1057,637 \mathrm{~cm}^{-1} ;{ }^{1} \mathrm{H}$ NMR $\left(\mathrm{CDCl}_{3}\right): \delta 8.39(1 \mathrm{H}, \mathrm{s}, \mathrm{CHN}), 5.39\left(2 \mathrm{H}, \mathrm{s}, \mathrm{C}-1^{\prime}\right), 4.37\left(2 \mathrm{H}, \mathrm{q}, \mathrm{CH}_{3} \mathrm{CH}_{2} \mathrm{O}\right.$, $\mathrm{J}=7.1 \mathrm{~Hz}), 4.16\left(2 \mathrm{H}, \mathrm{t}, \mathrm{CH}_{2} \mathrm{O}_{2}, \mathrm{~J}=4.7 \mathrm{~Hz}\right), 3.66\left(2 \mathrm{H}, \mathrm{t}, \mathrm{OCH}_{2}, \mathrm{~J}=4.7 \mathrm{~Hz}\right)$, $2.03\left(3 \mathrm{H}, \mathrm{s}, \mathrm{CO}_{2} \mathrm{CH}_{3}\right), 1.40\left(3 \mathrm{H}, \mathrm{t}, \mathrm{CH}_{3} \mathrm{CH}_{2}, \mathrm{~J}=7.1 \mathrm{~Hz}\right)$; Anal calcd for $\mathrm{C}_{14} \mathrm{H}_{15} \mathrm{~N}_{4} \mathrm{O}_{4} \mathrm{Br}$ : C, 43.88; H, 3.95; N, 14.62. Found: $\mathrm{C}, 43.71 ; \mathrm{H}, 4.09 ; \mathrm{N}, 14.80$. 
4-Amino-6-bromo-7-[(2-hydroxyethoxy) methyl]pyrrolo[2,3-d]pyrimidine-5carbonitrile (4). To $100 \mathrm{ml}$ of saturated methanolic ammonia in a pressure bottle at $25^{\circ} \mathrm{C}$ was added compound $3(2.60 \mathrm{~g}, 6.78 \mathrm{mmol})$. The bottle was sealed and the solution stirred for $24 \mathrm{~h}$ at room temperature. The resulting suspension was cooled to $-78^{\circ} \mathrm{C}$ then filtered to yield $1.89 \mathrm{~g}(89 \%)$ of $4: \mathrm{mp}$ $235-236^{\circ}(\mathrm{d})$; TLC, (40:9:1 EtOAc/MeOH/H $/ \mathrm{H}_{2} \mathrm{O}$, v:v) $\mathrm{Rf}=0.71$ : UV $1 \max \left(\varepsilon_{\mathrm{mM}}\right)$ (pH 1) 230 (15), 282 (16); (EtOH), 285 (16); (pH 11) 229 (11), 285 (16); FTIR $(\mathrm{KBr}) v_{\max } 3569,3366,3329,3116,2942,2225,1666,1649,1596,1364,1306$, $1115,1051,792 \mathrm{~cm}^{-1}$; ${ }^{1} \mathrm{H}$ NMR: $\delta 8.24(1 \mathrm{H}, \mathrm{s}, \mathrm{C}-2), 7.00\left(2 \mathrm{H}, \mathrm{s}, \mathrm{NH}_{2}, \mathrm{D}_{2} \mathrm{O}\right.$ exchangeable), $5.62\left(2 \mathrm{H}, \mathrm{s}, \mathrm{C}-1^{\prime}\right), 4.66\left(1 \mathrm{H}, \mathrm{t}, \mathrm{OH}, \mathrm{D}_{2} \mathrm{O}\right.$ exchangeable, $\mathrm{J}=5.2$ $\mathrm{Hz}$ ), 3.49-3.43 (4H, m, $\left.\mathrm{CH}_{2}\right)$; Anal calcd for $\mathrm{C}_{10} \mathrm{H}_{10} \mathrm{~N}_{5} \mathrm{O}_{2} \mathrm{Br}$ : C, 38.48; $\mathrm{H}, 3.23$; $\mathrm{N}, 22.45$. Found: $\mathrm{C}, 38.62 ; \mathrm{H}, 3.35 ; \mathrm{N}, 22.55$.

4-Amino-7-[(2-hydroxyethoxy) methyl]pyrrolo[2,3-d]pyrimidine-5-carbonitrile (5). Compound $4(2.47 \mathrm{~g}, 8.0 \mathrm{mmol})$ was dissolved in a mixture of EtOAc and EtOH $(2: 1 \mathrm{v}: \mathrm{v} ; 150 \mathrm{ml})$ containing $5 \mathrm{ml}$ of $1 \mathrm{~N} \mathrm{NH} \mathrm{NH}_{4} \mathrm{OH}$. Palladium-carbon $(10 \% ; 593 \mathrm{mg})$ was added, and the reaction mixture was hydrogenated at $42 \mathrm{psi}$ at room temperature for $12 \mathrm{~h}$. The mixture was filtered, the filtrate evaporated in vacuo and the resulting solid adsorbed onto silica gel $(7.5 \mathrm{~g})$ then subjected to column chromatography in $\mathrm{MeOH} / \mathrm{CHCl}_{3}(5: 95$, v:v) to yield $1.19 \mathrm{~g} 5$ (63\%): mp 186-188 ; TLC, $\mathrm{MeOH} / \mathrm{EtOAc} / \mathrm{CHCl}_{3}(1: 1: 5, \mathrm{v}: \mathrm{v}) \mathrm{Rf}=0.28 ;{ }^{1} \mathrm{H}$ NMR: $\delta 8.34(1 \mathrm{H}, \mathrm{s}, \mathrm{C}-2), 8.23(1 \mathrm{H}, \mathrm{s}, \mathrm{C}-6), 6.90\left(2\right.$, br s, $\mathrm{NH}_{2}, \mathrm{D}_{2} \mathrm{O}$ exchangeable), $5.56\left(2 \mathrm{H}, \mathrm{s}, \mathrm{C}-1^{\prime}\right), 4.67\left(1 \mathrm{H}, \mathrm{s}, \mathrm{OH}, \mathrm{D}_{2} \mathrm{O}\right.$ exchangeable $), 3.44$ $\left(4 \mathrm{H}, \mathrm{m}, \mathrm{CH}_{2}\right)$. All other spectroscopic data obtained for compound 5 was identical to that previously reported (Gupta et al., 1989a). A sample was recrystallized from EtOH for analysis: Anal calcd for $\mathrm{C}_{10} \mathrm{H}_{11} \mathrm{~N}_{5} \mathrm{O}_{2}: \mathrm{C}, 51.49 ; \mathrm{H}$, 4.75; N, 30.03. Found: C, 51.46; H, 4.77; N, 30.08.

4-Amino-7-[(2-hydroxyethoxy) methyl]pyrrolo[2,3-d]pyrimidine-5thiocarboxamide (229). Dry $\mathrm{H}_{2} \mathrm{~S}$ was passed through a solution of sodium methoxide $(1.5 \mathrm{~g}, 28 \mathrm{mmol})$ in dry methanol $(300 \mathrm{ml})$ for $0.5 \mathrm{~h}$. The nitrile 5 $(3.25 \mathrm{~g}, 13.9 \mathrm{mmol})$ was added in one portion, and the mixture was stirred in a sealed pressure vessel at $80^{\circ} \mathrm{C}$ for $1.5 \mathrm{~h}$. The resulting solution was allowed to cool to room temperature, then adjusted to $\mathrm{pH} 7$ with $1 \mathrm{~N} \mathrm{HCl}$. The solvent was rotary evaporated and the compound recrystallized from $\mathrm{H}_{2} \mathrm{O}$ containing a small amount of EtOH to yield $1.68 \mathrm{~g}$ of $229(45 \%)$ mp 199-200 ; TLC, $\mathrm{MeOH} / \mathrm{CHCl}_{3}$ (5:95, v:v) $\mathrm{Rf}=0.17 ;{ }^{1} \mathrm{H}$ NMR: $\delta 9.49$ and 9.52 (1 each, br s, $\mathrm{CSNH}_{2}, \mathrm{D}_{2} \mathrm{O}$ exchangeable $), 8.14(1 \mathrm{H}, \mathrm{s}, \mathrm{C}-2), 7.93\left(2 \mathrm{H}, \mathrm{s}, \mathrm{NH}_{2}, \mathrm{D}_{2} \mathrm{O}\right.$ exchangeable), $7.86(1 \mathrm{H}, \mathrm{s}, \mathrm{C}-6), 5.54\left(2 \mathrm{H}, \mathrm{s}, \mathrm{C}-1^{\prime}\right), 4.69\left(1 \mathrm{H}, \mathrm{s}, \mathrm{OH}, \mathrm{D}_{2} \mathrm{O}\right.$ exchangeable), $3.47\left(4 \mathrm{H}, \mathrm{m}, \mathrm{CH}_{2}\right)$. All other spectroscopic data obtained for compound 229 was identical to that previously reported (Gupta et al., 1989a); Anal calcd for $\mathrm{C}_{10} \mathrm{H}_{13} \mathrm{~N}_{5} \mathrm{O}_{2} \mathrm{~S}$ : C, 44.93; H, 4.90; N, 26.20. Found: C, 44.73; H, 4.79; N, 26.31. 


\section{Cell cultures}

KB cells, an established human cell line derived from an epidermal oral carcinoma, were routinely grown in MEM with Hanks' salts [MEM(H)] supplemented with $10 \%$ calf serum. Diploid cell cultures of HFF cells were grown in MEM with Earle salts [MEM(E)] supplemented with $10 \%$ fetal bovine serum. Cells were passaged by conventional procedures by using $0.05 \%$ trypsin and $0.02 \%$ EDTA in a HEPES ( $\mathrm{N}$-2-hydroxyethylpiperazine- $\mathrm{N}^{\prime}-2$ ethanesulfonic acid)-buffered salt solution (HBS) (Shipman et al., 1976). To increase the likelihood of detecting bacterial or mixed bacterial and mycoplasmal contamination, antibiotics were never used in the routine passage of cells (Hayflick, 1973). Cell lines were screened periodically and were mycoplasma-free.

\section{Antiviral assays}

The effect of compound 229 and DHPG on HCMV replication was determined by plaque and yield reduction assays. HCMV plaque reduction assays were performed with monolayer cultures of HFF cells. A plaque purified isolate, $\mathbf{P}_{0}$, of the Towne strain of HCMV obtained from Dr. M.F. Stinski, University of Iowa, was used. Preparation of HCMV stocks and the plaque assay are detailed elsewhere (Turk et al., 1987). The virus inoculum contained approximately 100 PFU of HCMV. Selected concentrations of the compound were dissolved in the medium and added $1 \mathrm{~h}$ after addition of virus. At 10-12 days plaques were enumerated microscopically at a magnification of 30 -fold. Yield (titer) reduction assays were performed as reported previously (Prichard et al., 1990). Monolayer cultures of HFF cells were infected at a multiplicity of infection of 0.5 PFU per cell and incubated in the presence of test compounds for 7-10 days. Following three cycles of freezing at $-76^{\circ} \mathrm{C}$ and thawing at $37^{\circ} \mathrm{C}$, the resulting lysates were diluted and the amount of infectious virus was quantitated on new cultures of HFF cells.

The activity of compounds against other herpes viruses was determined by plaque assay. The susceptibility of MCMV (Smith strain) to antiviral drugs was assayed by plaque assay in primary mouse embryo fibroblasts. The sensitivity of HSV-1 (E-377 strain), HSV-2 (MS strain), and VZV (Ellen strain) to compounds was determined in HFF cells by the plaque reduction assay. Confluent cell monolayers in 6-well plates were inoculated with 20-50 PFU of the appropriate virus and incubated at $37^{\circ} \mathrm{C}$ and $90 \%$ humidity for $1 \mathrm{~h}$. Serial 5-fold dilutions of each drug were prepared in twice concentrated MEM(E), mixed with an equal volume of a $1 \%$ agarose and $2 \mathrm{ml}$ of the mixture added to the monolayer cultures. An additional overlay mixture without drug $(1 \mathrm{ml})$ was added on day 4 for MCMV and on days 3 and 6 for VZV. At the appropriate time (HSV, 3 days; MCMV, 7 days; VZV, 10 days) monolayers were stained with neutral red and plaques enumerated either visually or with the aid of a stereo dissecting microscope. Drug-treated cultures were compared to untreated control cultures and $\mathrm{IC}_{50}$ values were calculated using a dose-effect analysis software program (Elsevier-Biosoft, Cambridge, U.K.). 


\section{Cell growth rates}

The inhibitory effect of compound 229 on KB cell growth was studied and population doubling time and cell viability were determined as detailed elsewhere (Nassiri et al., 1990). Briefly, 6-well plastic tissue culture dishes were seeded with 80,000 or 100,000 cells per well. Approximately $24 \mathrm{~h}$ later, the medium from the wells was aspirated and fresh medium with or without selected concentrations of drug was added. The incubation period was continued to 96 or $120 \mathrm{~h}$ at $37^{\circ} \mathrm{C}$. Every $24 \mathrm{~h}$, cultures were harvested by means of $0.05 \%$ trypsin plus $0.02 \%$ EDTA in HBS. Cells were enumerated by using a Coulter Counter (model ZF, Coulter Electronics, Hialeah, FL). Viability of untreated cultures were periodically checked by trypan blue dye exclusion. Control cells showed a viability of $>95 \%$. Population doubling times were calculated by means of a least squares program fitting the exponential portion of the growth curve.

\section{Plating efficiency}

Plating efficiencies were carried out by procedures described earlier (Nassiri et al., 1991a). Briefly, KB cells were diluted with medium and planted in tissue culture dishes $(150 \times 25 \mathrm{~mm}$, Falcon, Oxnard, CA) for a final concentration of 500-650 cells per dish. After an incubation period of 12-14 days, medium was removed and cells were rinsed with buffer solution then fixed with absolute methanol. After $2 \mathrm{~min}$, the cells were stained with $0.1 \%$ crystal violet and clones $>1 \mathrm{~mm}$ in diameter were enumerated.

\section{Flow cytometry}

DNA-flow cytometry was carried out by procedures outlined earlier (Nassiri et al., 1990) with several modifications to be detailed elsewhere (Nassiri et al., manuscript in preparation). Briefly, untreated and drug-treated HFF cells were fixed in $70 \%$ ethanol for a minimum of $24 \mathrm{~h}$. When ready for flow cytometric analysis, the cells were pelleted and resuspended in $500 \mu \mathrm{l}$ of DNase $(1 \mathrm{mg} / \mathrm{ml}$ of $2340 \mathrm{U} / \mathrm{mg}$, Sigma, St. Louis, MO) per $10^{6}$ cells and incubated at $37^{\circ} \mathrm{C}$ for 45 min. $100 \mu \mathrm{l}$ of $1 \mathrm{mg} / \mathrm{ml}$ propidium iodide reagent (PI, Sigma, St. Louis, MO) was added to the suspension containing $1 \times 10^{6}$ cells which was chilled on ice water for $60 \mathrm{~min}$. Propidium stained nuclei were analyzed on an EPICS V Flow Cytometer fitted with an argon-ion laser emitting at $488 \mathrm{~nm}(400 \mathrm{~mW})$, a 515 $\mathrm{nm}$ long pass filter, a $560 \mathrm{~nm}$ dichroic filter and a $630 \mathrm{~nm}$ long pass filter (red, DNA). Chicken erythrocytes were added in amounts equal to $20 \%$ of each sample preparation as internal biological standards. In all samples, a total of 10,000 nuclei were analyzed. Percentage estimates of cells in $G_{0} / G_{1}, S$ and $G_{2} /$ $\mathrm{M}$ phases were made using an integration software analysis package provided with the flow cytometer for the Easy II computer (Coulter Electronics, Hialeah, FL).

\section{Data analysis}

Dose-response relationships were used to quantitate drug effects. These were 
constructed by linearly regressing the percent inhibition of parameters derived in the preceding sections against log drug concentrations. The $50 \%$ inhibitory $\left(\mathrm{IC}_{50}\right)$ concentrations were calculated from the regression lines using the methods described by Goldstein (1964). Ganciclovir (DHPG; kindly provided by Syntex Corporation, San Francisco, CA) was used as a positive control in all antiviral assays.

\section{Results}

\section{Chemistry}

The original synthesis of compound 229 (Gupta et al., 1989a) was not suitable for multi-gram synthesis and the first step in the reaction scheme itself resulted in an isomeric mixture of alkylated products. We have utilized the approach of Ramasamy (1986) which fixes the site of alkylation on the pyrrole and have also reduced the total steps in the synthesis of compound 229 (Fig. 1). The alkylated pyrrole 3 was obtained in $55 \%$ yield by treatment of the known pyrrole (Swayze et al., 1991) (1) with triethylorthoformate followed by the addition of sodium hydride and (2-acetoxyethoxy)methyl bromide (Robins and Hatfield, 1982). Ring annulation and removal of the protecting group was achieved with saturated methanolic ammonia in a pressure bottle at room temperature to give 4 in excellent yield $(89 \%)$. Debromination of 4 via catalytic hydrogenation gave 5 which, when treated with methanolic sodium hydrosulfide generated in situ, gave 229 in a two-step yield of $28 \%$. The overall yield for the new synthesis of compound 229 was $14 \%$ compared to the original value of $0.6 \%$ (Gupta et al., 1989a). Subsequent runs on a smaller scale have given compound 229 in yields of approximately $40 \%$ from 1 .

\section{Biological evaluation}

Antiviral activity. In our initial studies, compound 229 was moderately active against $\mathrm{HCMV}$ in plaque-reduction assays with an $\mathrm{IC}_{50}$ of $11 \mu \mathrm{M}$ (Gupta et al., 1989a). In three separate experiments in the current study the average activity

TABLE 1

Activity of compound 229 against selected herpesviruses

\begin{tabular}{|c|c|c|c|c|}
\hline \multirow[t]{2}{*}{ Virus } & \multirow[t]{2}{*}{ Cell line ${ }^{\mathrm{a}}$} & \multicolumn{3}{|c|}{$50 \%$ inhibitory concentration $(\mu \mathrm{M})^{\mathrm{b}}$} \\
\hline & & Compound 229 & Ganciclovir & Acyclovir \\
\hline HCMV & human foreskin fibroblasts & 7 & 10 & - \\
\hline MCMV & mouse embryo fibroblasts & 16 & 2.6 & - \\
\hline HSV-1 & human foreskin fibroblasts & 21 & - & 1.3 \\
\hline HSV-2 & human foreskin fibroblasts & 30 & - & 3.6 \\
\hline VZV & human foreskin fibroblasts & 46 & - & 9.3 \\
\hline
\end{tabular}

${ }^{a}$ Used to propagate the virus and assess visual cytotoxicity.

${ }^{b}$ Virus strains and plaque assays described in the text, average of two or more experiments. 
<smiles>N#Cc1c(N)[nH]c(Br)c1C#N</smiles><smiles>[Y]C#CC</smiles><smiles></smiles><smiles>CCO/C=N/c1c(C#N)c(C#N)c(Br)n1COCCOC(C)=O</smiles><smiles></smiles>

5

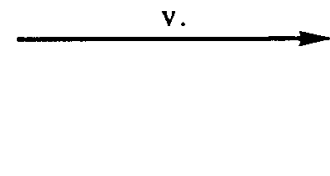$$
\text { Hoר }
$$

Compound 229

Fig. 1. Synthesis of 4-amino-7-[(2-hydroxyethoxy)methyl]pyrrolo[2;3-d]pyrimidine-5-thiocarboxamide (compound 229). Numbered reactants are as follows: i. $\mathrm{CH}(\mathrm{OEt})_{3}, \mathrm{CH}_{3} \mathrm{CN}$ ii. NaH, (2-acetoxyethoxy)methyl bromide iii. $\mathrm{NH}_{3}, \mathrm{MeOH}$ iv. $\mathrm{Pd} / \mathrm{C}(10 \%), \mathrm{H}_{2}$ v. $\mathrm{NaOMe}, \mathrm{MeOH}$ and $\mathrm{H}_{2} \mathrm{~S}$.

against HCMV in a plaque reduction assay was $7 \mu \mathrm{M}$ for compound 229 and $10 \mu \mathrm{M}$ for ganciclovir (Table 1). Compound 229 was somewhat less active than

\section{TABLE 2}

Population doubling times of KB cells treated with compound $229^{\mathrm{a}}$

$\begin{array}{llllll}\text { Concentration of compound } 229(\mu \mathrm{M}) & 0 & 10 & 32 & 100 & 100 \text { (reversal) }\end{array}$

Population doubling time $(\mathrm{h})$ $\begin{array}{lllll}21.0 & 21.5 & 23.5 & 34.7 & 23.9\end{array}$

${ }^{a}$ Results are from duplicate cultures. Experiment was performed two times. 


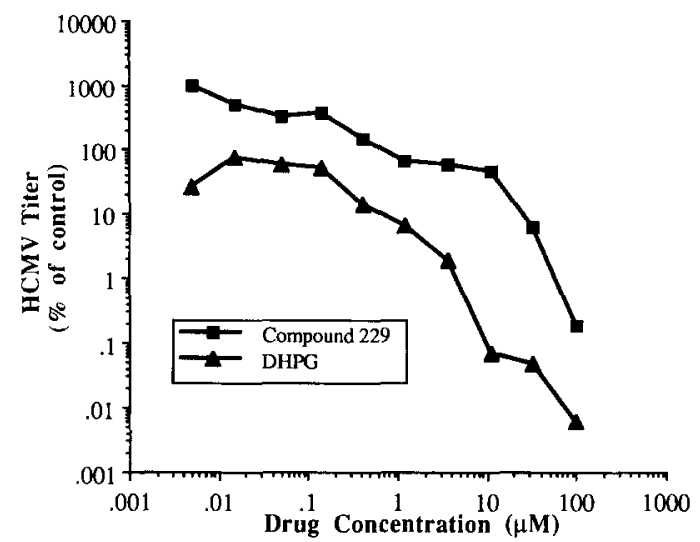

Fig. 2. Effect of compound 229 and DHPG on the replication of HCMV. Subconfluent monolayers of HFF cells were infected at a multiplicity of infection of $0.5 \mathrm{PFU}$ per cell and incubated in the presence of test compounds for 7 days. Infectious virus present at that time was quantitated by plaque assay on HFF cells as described in the text. Average data from two experiments are presented.

ganciclovir against MCMV and was least active against HSV-1, HSV-2 and VZV (Table 1). In previous work (Gupta et al., 1989a), we found slight activity ( $\sim 30 \%$ inhibition) against $\mathrm{HSV}-1$ at $100 \mu \mathrm{M}$. In more extensive evaluations,

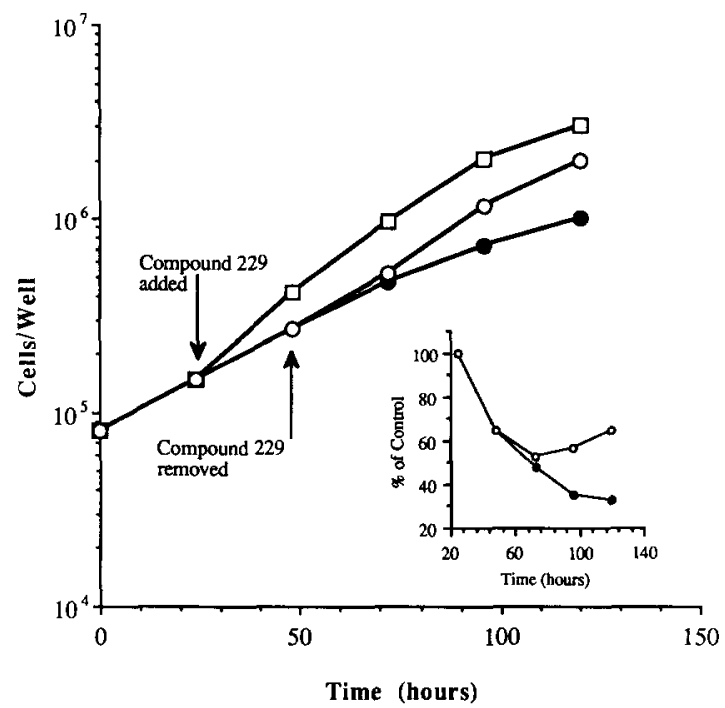

Fig. 3. Reversibility of inhibition of KB cell growth by compound 229 . Cells were seeded at 80,000 cells per well and incubated for $24 \mathrm{~h}$ at which time $100 \mu \mathrm{M}$ compound 229 was added to two sets of cultures $(\mathrm{O}, \mathrm{O})$ and incubated for an additional $24 \mathrm{~h}$. At that time, medium was removed from one set of drug-containing cultures $(O)$ and following a rinse with medium, the cultures were incubated with drug free medium. Cells were subsequently harvested at selected time periods up to $120 \mathrm{~h}$ and enumerated with a Coulter counter. Inset: plot (as percent of cells in control cultures) of total KB cells in cultures continually treated with 100 $\mu \mathrm{M}$ compound $229(\mathrm{)})$ and cultures from which drug was removed after $24 \mathrm{~h}(\mathrm{O})$. Similar results were obtained in two separate experiments. 


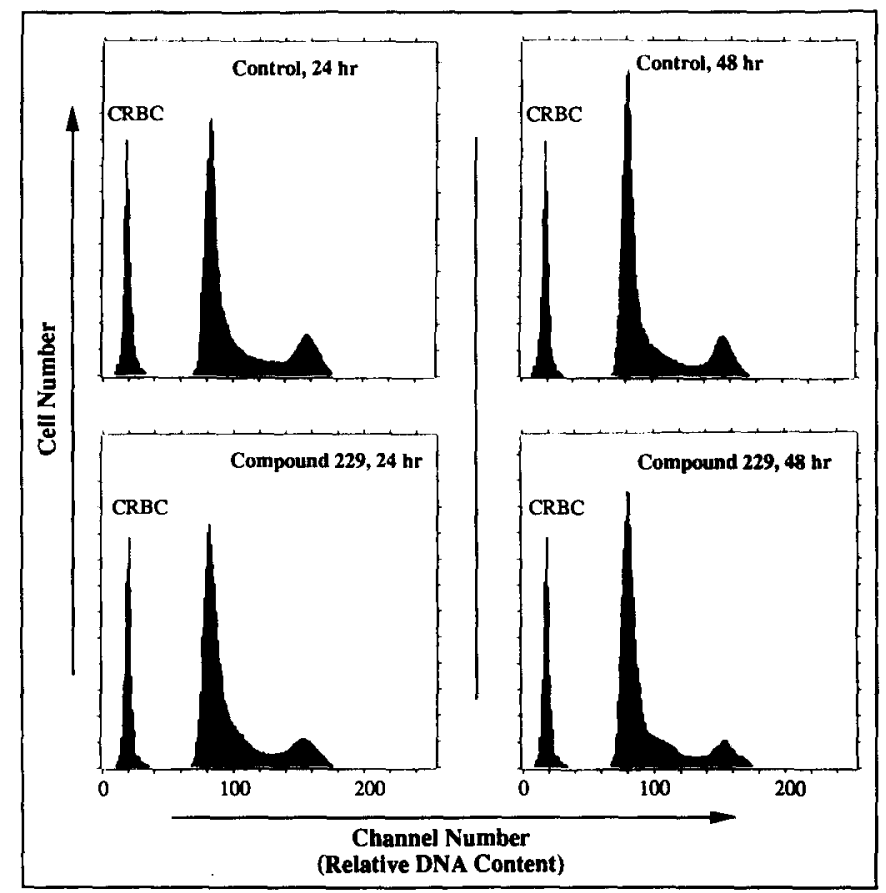

Fig. 4. Flow histograms illustrating the response of HFF cells to $100 \mu \mathrm{M}$ compound 229 for 24 and $48 \mathrm{~h}$. Percentages of $G_{0} / G_{1}, S$ and $G_{2} / M$ were determined as described in the text: Control, $24 \mathrm{~h}: \mathrm{G}_{0} / \mathrm{G}_{1}, 54 ; \mathrm{S}$, $27 ; \mathrm{G}_{2} / \mathrm{M}, 19$. Compound $229,24 \mathrm{~h}: \mathrm{G}_{0} / \mathrm{G}_{1}, 53 ; \mathrm{S}, 33 ; \mathrm{G}_{2} / \mathrm{M}, 14$. Control $48 \mathrm{~h}: \mathrm{G}_{0} / \mathrm{G}_{1}, 64 ; \mathrm{S}, 24 ; \mathrm{G}_{2} / \mathrm{M}, 12$. Compound $22948 \mathrm{~h}: \mathrm{G}_{0} / \mathrm{G}_{1}, 65 ; \mathrm{S}, 28 ; \mathrm{G}_{2} / \mathrm{M}, 7$.

compound 229 was less active than ganciclovir in yield reduction experiments (Fig. 2) $\left(\mathrm{IC}_{90}=25 \mu \mathrm{M}\right.$ vs. $1 \mu \mathrm{M}$, respectively). Compound 229 reduced HCMV titer by more than three $\log _{10}$ units (>1000-fold) at $100 \mu \mathrm{M}$ compared to a greater than four $\log _{10}$ reduction by ganciclovir.

Effects on uninfected cells. The effect of compound 229 on the growth of uninfected KB cells was examined as a measure of drug cytotoxicity. Compound 229 slightly suppressed the growth of KB cells at 10 and $32 \mu \mathrm{M}$. Population doubling times increased from $21 \mathrm{~h}$ in the control to $21.5 \mathrm{~h}$ with 10 $\mu \mathrm{M}$ and $23.5 \mathrm{~h}$ with $32 \mu \mathrm{M}$ (Table 2 ). Cells continued to grow at concentrations up to $100 \mu \mathrm{M}$, where the population doubling time increased to $34.7 \mathrm{~h}$. Cells did not grow in the presence of $320 \mu \mathrm{M}$.

The inhibition observed at $100 \mu \mathrm{M}$ was reversible upon removal of the drug following a $24 \mathrm{~h}$ incubation period (Fig. 3). After the removal of compound 229 , cell growth recovered to a population doubling time of $23.9 \mathrm{~h}$ (Table 2). This is more obvious in the inset which shows that the percentage of KB cells treated with $100 \mu \mathrm{M}$ compound 229 increased after the removal of the compound, whereas the number of cells in the treated cultures continued to decline. 
The ability of KB cells to attach to a substrate and clone in the presence of selected concentrations of compound 229 and DHPG was evaluated. We have found plating efficiency to be a technique often more sensitive than cell growth to evaluate cytotoxicity. Compound 229 had an $\mathrm{IC}_{50}$ value of $23 \mu \mathrm{M}$ compared to an $\mathrm{IC}_{50}$ of $51 \mu \mathrm{M}$ for ganciclovir (data not shown).

As an additional and detailed measure of cytotoxicity, perturbations in the cell cycle caused by compound 229 were measured by utilizing DNA flow cytometry (Barlogie et al., 1983; Gray and Coffino, 1979; Nassiri et al., 1990). Incubation of $100 \mu \mathrm{M}$ compound 229 for 24 and $48 \mathrm{~h}$ with HFF cells resulted in an accumulation of cells in early $S$ phase with a concurrent reduction of cells in $\mathrm{G}_{2} / \mathbf{M}$ phase (Fig. 4). These data are consistent with an early $\mathrm{S}$ phase blockage and with the cell growth studies which showed inhibition of cell growth at 100 $\mu \mathrm{M}$. The effect of $100 \mu \mathrm{M}$ compound 229 on the cell cycle of KB cells was essentially the same as HFF cells at 12,36, 48 and $72 \mathrm{~h}$ of treatment (data not shown). Concentrations of 10 and $32 \mu \mathrm{M}$ over similar time periods showed no significant perturbations in the cycle of KB cells compared to control (data not shown). In other flow cytometry studies, we found that ganciclovir had a minor effect on the KB cell cycle at $100 \mu \mathrm{M}$. There appeared to be a $4 \%$ decrease in the total number of cells in $\mathrm{G}_{0} / \mathrm{G}_{1}$ with a similar increase in the number of cells in $\mathrm{S}$ phase. These effects, however, were not statistically significant by Student's $t$-test.

\section{Discussion}

In the present study, we have described the multi-gram synthesis of an acyclic analog of thiosangivamycin; examined or re-examined the activity against selected herpesviruses including HCMV, MCMV, HSV-1, HSV-2 and VZV; and evaluated the cytotoxicity of the compound in uninfected cells using cell growth studies, plating efficiency and DNA flow cytometry. In cell growth experiments, the inhibitory effect of this compound was not immediate and did not dramatically affect the growth of KB cells up to $100 \mu \mathrm{M}$. But even this effect was reversible, suggesting that compound 229 is acting as a cytostatic rather than a cytotoxic agent. This raises the possibility that the compound may inhibit DNA polymerase rather than be a substrate and act as a chain terminator.

Flow cytometry results from two separate cell lines suggest that compound 229 may be interfering with the progression of cells through $S$ phase since there is an increase in the percentage of cells $S$ phase coupled with a loss of cells in $\mathrm{G}_{2} / \mathrm{M}$. The overall cell cycle perturbation was modest. Interestingly, two other acyclic 4-amino-5-substituted pyrrolo[2,3- $d$ ]pyrimidines act as $\mathrm{S}$ phase blockers (Nassiri et al., 1990). These compounds are 5-bromotubercidin analogs which differ from compound 229 in that one is an acyclovir analog (4-amino-5bromo-7-[(2-hydroxyethoxy)methyl]pyrrolo[2,3-d]pyrimidine, compound 102) and the other a ganciclovir analog (4-amino-5-bromo-7-[(1,3-dihydroxy-2- 
propoxy)methyl]pyrrolo[2,3-d]pyrimidine, compound 183). Like compound 229 , the effects of compound 102 on uninfected cells were reversible upon removal of the compound, whereas the removal of compound 183 did not reverse growth inhibition. Furthermore, cells treated with compound 229 morphologically resembled those treated with compound 102 , not compound 183. Unlike compound 229, compound 102 blocked the progression of the cell cycle at mid S phase whereas, like compound 229, compound 183 blocked cells at late $G_{0} / G_{1}$ and early $S$ phase. The inhibitory effects of both compounds 102 and 183 , though, were observed at $10 \mu \mathrm{M}$ compared to $100 \mu \mathrm{M}$ for compound 229. Based upon these comparisons, compound 229 may be acting by a cellular mechanism which is different from either compound 102 or 183 even though all three are pyrrolo[2,3- $d]$ pyrimidine analogs. The exact mechanism underlying this phenomenon is under investigation.

Although compound 229 was not as efficacious as ganciclovir in yield reduction assays against HCMV and was slightly more cytotoxic, this study provides insights into a new class of pyrrolo[2,3-d]pyrimidines which are worthy of further investigation.

\section{Acknowledgements}

We thank Jack Hinkley, Edward Kreske and Caroll Hartline for expert assistance with chemical and virological techniques. We also thank Patricia Whittler and Rae Herrst for preparation of the manuscript. This study was supported by federal funds from the Health and Human Services under Contracts NO1-AI42554, AI72641 and AI82518 from the National Institute of Allergy and Infectious Diseases.

\section{References}

Barlogie, B., Raber, M.N., Schumann, J., Johnson, T.S., Drewinko, B., Swartzendruber, D.E., Gode, W., Andreeff, M. and Freireich, E.J. (1983) Flow cytometry in clinical cancer research. Cancer Res. 43, 3982-3997.

Bowden, R.A. (1991) Cytomegalovirus infections in transplant patients: methods of prevention of primary cytomegalovirus. Transplant. Proc. 23, 136-138.

Collaborative DHPG treatment study group (1986) Treatment of serious cytomegalovirus infections with 9-(1,3-dihydroxy-2-propoxymethyl)guanine in patients with AIDS and other immunodeficiences. N. Engl. J. Med. 314, 801-805.

Crumpacker, C.S., Schnipper, L.E., Zaia, J.A. and Levin, M.J. (1979) Growth inhibition by acycloguanosine of herpesviruses isolated from human infections. Antimicrob. Agents Chemother. 15, 642-645.

Demmler, G.J. (1991) Infectious Diseases Society of America and Centers for Disease Control, Summary of a workshop on surveillance for congenital cytomegalovirus disease. Rev. Infectious Dis. 13, 315-329.

Elion, G.B., Furman, P.A., Fyfe, J.A., De Miranda, P., Beauchamp, L. and Schaeffer, H.J. (1977) Selectivity of action of an antiherpetic agent, 9-(2-hydroxyethoxymethyl)guanine. Proc. Natl. Acad. Sci. USA 74, 5716-5720.

Fyfe, J.A., Keller, P.M., Furman, P.A., Miller, R.L. and Elion, G.B. (1978) Thymidine kinase from 
herpes simplex virus phosphorylates the new antiviral compound, 9-(2-hydroxyethoxymethyl)guanine. J. Biol. Chem. 253, 8721-8727.

Goldstein, A. (1964) Biostatistics, an introductory text. MacMillan, New York, pp. 156-161.

Gray, J.W. and Coffino, P. (1979) Cell cycle analysis by flow cytometry. Methods Enzymol. 58, 233248.

Gupta, P.K., Nassiri, M.R., Coleman, L.A., Wotring, L.L., Drach, J.C. and Townsend, L.B. (1989a) Synthesis, cytotoxicity and antiviral activity of certain 7-[(2-hydroxyethoxy)methyl]pyrrolo[2,3-d]pyrimidine nucleosides related to toyocamycin and sangivamycin. J. Med. Chem. 32, 1420-1425.

Gupta, P.K., Daunert, S., Nassiri, M.R., Wotring, L.L., Drach, J.C. and Townsend, L.B. (1989b) Synthesis, cytotoxicity and antiviral activity of some acyclic analogues of the pyrrolo[2,3d]pyrimidine nucleoside antibiotics tubercidin, toyocamycin and sangivamycin. J. Med. Chem. $32,402-408$.

Hayflick, L. (1973) Screening tissue cultures for mycoplasma infections. In: P.F. Kruse Jr. and M.K. Patterson, Jr. (Eds), Tissue culture: Methods and applications, pp. 722-728. Academic Press, New York.

Mills, J. and Masur, H. (1990) AIDS-related infections. Sci. Am. 263, 50-57.

Nassiri, M.R., Hudson, J.L., Pudlo, J.S., Birch, G.M., Townsend, L.B. and Drach, J.C. (1990) Flow cytometric evaluation of the cytotoxicity of novel antiviral compounds. Cytometry 11, 411-417.

Nassiri, M.R., Flynn, G.L. and Shipman, C. Jr. (1991a) Inhibition of cell growth and DNA, RNA and protein synthesis in vitro by fentanyl, sufentanil and opiate analgesics. Pharmacol. Toxicol. $69,17-21$.

Nassiri, M.R., Turk, S.R., Birch G.M., Coleman, L.A., Hudson, J.L., Pudlo, J.S., Townsend, L.B. and Drach, J.C. (1991b) Activity of acyclic halogenated tubercidin analogs against human cytomegalovirus and in uninfected cells. Antiviral Res. 16, 135-150.

Prichard, M.N., Turk, S.R., Coleman, L.A., Engelhardt, S.L., Shipman, C. Jr. and Drach, J.C. (1990) A microtiter virus yield reduction assay for the evaluation of antiviral compounds against human cytomegalovirus and herpes simplex virus. J. Virol. Methods 28, 101-106.

Pudlo, J.S., Saxena, N.K., Nassiri, M.R., Turk, S.R., Drach, J.C. and Townsend, L.B. (1988) Synthesis and antiviral activity of certain 4- and 4,5-disubstituted 7-[(2-hydroxyethoxy)methyl]pyrrolo[2,3-d]pyrimidines. J. Med. Chem. 31, 2086-2092.

Pudlo, J.S., Nassiri, M.R., Kern, E.R., Wotring, L.L., Drach, J.C. and Townsend, L.B. (1990) Synthesis, antiproliferative and antiviral activity of certain 4-substituted and 4,5-disubstituted 7[(1,3-dihydroxy-2-propoxy)methyl]pyrrolo[2,3-d]pyrimidines. J. Med. Chem. 33, 1984-1992.

Ramasamy, K., Robins, R.K. and Revankar, G.R. (1986) Total synthesis of 2'-deoxytoyocamycin, $2^{\prime}$-deoxysangivamycin and related $7-\beta$-D-arabinofuranosylpyrrolo[2,3- $\left.d\right]$ pyrimidines via ring closure of pyrrole precursors prepared by the stereospecific salt glycosylation procedure. Tetrahedron 42, 5869-5878.

Robins, M.J. and Hatfield, P.W. (1982) Nucleic acid related compounds. 37. Convenient and highyield syntheses of $\mathrm{N}-[(2$-hydroxyethoxy)methyl] heterocycles as 'acyclic nucleoside' analogues. Can. J. Chem. 60, 547-553.

Saxena, N.K., Hagenow, B., Genzlinger, G., Turk, S.R., Drach, J.C. and Townsend, L.B. (1988) Synthesis and antiviral activity of certain 4-substituted and 2,4-disubstituted 7-[(2-hydroxyethoxy)methyl]pyrrolo[2,3-d]pyrimidines. J. Med. Chem. 31, 1501-1506.

Shepp, D.H., Dandliker, P.S., de Miranda, P., Burnette, T., Cederberg, D.M., Kirk, L.E. and Meyers, J.D. (1985) Activity of 9-[2-hydroxy-1-(hydroxymethyl)ethoxymethyl]guanine in the treatment of cytomegalovirus pneumonia. Ann. Intern. Med. 103, 368-373.

Shipman, C. Jr., Smith, S.H., Carson, R.H. and Drach, J.C. (1976) Antiviral activity of arabinosyladenine and arabinosylhypoxanthine in herpes simplex virus-infected $\mathrm{KB}$ cells: selective inhibition of viral deoxyribonucleic acid synthesis in synchronized suspension cultures. Antimicrob. Agents Chemother. 9, 120-127.

Still, W.C., Kahn, M. and Mitra, A. (1978) Rapid chromatographic technique for preparative separations with moderate resolution. J. Org. Chem. 43, 2923-2925.

Swayze, E.E., Hinkley, J.M. and Townsend (1991) In: L.B. Townsend and R.S. Tipson (Eds), 
Nucleic acid chemistry; improved and new synthetic procedures, methods and techniques, Part IV, pp. 16-18. Wiley-Interscience, New York.

Tolman, R.L., Robins, R.K. and Townsend, L.B. (1969) Pyrrolopyrimidine nucleosides. III. The total synthesis of toyocamycin, sangivamycin, tubercidin and related derivatives. J. Am. Chem. Soc. 91, 2102-2108.

Townsend, L.B., Drach, J.C., Wotring, L.L., Vittori, S., Pudlo, J.S., Swayze, E.E., Gupta, P., Maruyama, T., Saxena, N., Coleman, L.A., Westerman, A.C., Spurr, J.J., Nassiri, M.R., Turk, S.R. and Krawczyk, S.H. (1991) Design, synthesis and studies on the structure activity relationships of certain pyrrolo[2,3-d]pyrimidine nucleosides and structurally related analogs as potential antineoplastic and antiviral agents. Il Farmaco 46, 113-139.

Turk, S.R., Shipman, C. Jr., Nassiri, M.R., Genzlinger, G., Krawczyk, S.H., Townsend, L.B. and Drach, J.C. (1987) Pyrrolo[2,3-d]pyrimidine nucleosides as inhibitors of human cytomegalovirus. Antimicrob. Agents Chemother. 31, 544-550.

Tyms, A.S., Scamans, E.M. and Naim, H.M. (1981) The in vitro activity of acyclovir and related compounds against cytomegalovirus infections. J. Antimicrob. Chem. 8, 65-72. 